\title{
A toolbox to evaluate data reliability for whole-ecosystem models: Application on the Bay of Biscay continental shelf food-web model
}

\author{
Géraldine Lassalle $^{a, b, c, *}$, Pierre Bourdaud ${ }^{a, b}$, Blanche Saint-Béat ${ }^{a}$, Sébastien Rochette ${ }^{d}$, \\ Nathalie Niquil ${ }^{b}$
}

\begin{abstract}
${ }^{a}$ Littoral Environnement et Sociétés, UMR 7266 CNRS-Université de La Rochelle, 2 rue Olympe de Gouges, 17042 La Rochelle cedex, France

b CNRS, UMR 7208 BOREA, Institut de Biologie Fondamentale et Appliquée, Université de Caen BasseNormandie, Esplanade de la Paix, CS 14032, 14032 CAEN cedex 5; France

' IRSTEA, UR EABX, Aquatic Ecosystems and Global Changes, 50 avenue de Verdun, 33612 Cestas cedex, France

d Ifremer, Département Dynamiques de l'Environnement Côtier, Laboratoire Applications Géomatiques, CS 10070, 29280 Plouzané, France
\end{abstract}

*: Corresponding author: Géraldine Lassalle, tel.: +33 557890802 ;

email addresses : geraldine.lassalle@irstea.fr ; geraldinelassalle2@hotmail.com

p.I.e.bourdaud@gmail.com ; blanche.saint-beat@univ-Ir.fr ; sebastien.rochette@ifremer.fr ; nathalie.niquil@unicaen.fr

\begin{abstract}
:
Ecosystem models are always simplifications of reality and as such their application for ecosystem-based management requires standard validation. Here, the "DataReli" toolbox is proposed to evaluate the quality of the data used during the construction of ecosystem models, their coherence across trophic levels, and whether data limitations prevent the model long-term applications. This toolbox is the combination of three operational and complementary analyses: (i) the pedigree index to determine to what extent a model was calibrated on data of local origin; (ii) the graphical analysis known as PREBAL to assess whether a model respects some basic ecological and fisheries principles; and (iii) a sensitivity analysis to evaluate the robustness of model predictions to small variations in input data. The toolbox is delivered to potential users with main generic recommendations on how interpreting results conjointly and on which decisions to make about parameters' revisions or model uses' restrictions. (i) Corrections of parameters should be preferentially envisaged when modelling data-rich environments. (ii) For those models with an overall pedigree index above 0.4 , a closer look at the pedigree routine, i.e. values by parameters and compartments, and the PREBAL analysis would help to prioritize parameters needing improvement. (ii)' For Ecopath models of no overall acceptable quality (overall pedigree index <0.4), we recommend stopping the DataReli procedure at this point. (iii) In terms of sensitivity analysis, marked responses of model predictions to small variations in the input values must preferentially lead to restrictions in the model applications compared to corrections of parameter estimates. A concrete application of the "DataReli" toolbox to the pre-existing Ecopath model of the Bay of Biscay continental shelf food web is presented. For the present case study, the general level of input data reliability is considered as satisfying with regard to the model applications.
\end{abstract}

\section{Highlights}

Evaluation of parameter uncertainty in ecosystem models is primordial. An operational toolbox composed of three complementary analyses is proposed. The toolbox is applied on the Bay of Biscay Ecopath food web model. Model evaluation may lead to parameter revisions or model uses' restrictions.

Keywords: Food-web model ; Ecopath ; Model evaluation ; Parameter uncertainty ; Ecosystem-based management ; Bay of Biscay 
To ensure the usability of ecosystem models in the growing context of ecosystem-based management (Browman et al., 2004), one must know their capabilities and limitations (i.e. unknowns and caveats). Model limitations are generally divided into uncertainties originating from the data used during model construction (Gardner and O'Neill, 1983; Lehuta et al., 2010; Kearney et al., 2013, i.e. their quality generally referring to their origin and their quantity) and those in relation to the model structure (Gardner et al., 1982; Fulton et al., 2003; Hill et al., 2007; Johnson et al., 2009, i.e. the number of compartments, the level of taxa aggregation into compartments and the marine domain targeted in the model (benthos, pelagos or the entire continuum)).

The use of Ecopath to build mass-balance food-web models (Christensen and Walters, 2004;

Christensen et al., 2008) has increased over 20-fold in the last 15 years (Dame and Christian, 2006; Fulton, 2010). While structural uncertainty was rather seldom studied (e.g. Pinnegar et al., 2005), several methods are now available for this specific modelling software to address the issue of inherent uncertainties in the input data. Among these methods, some are implemented in the Ecopath software and used routinely while others are detailed in recent scientific publications (Kavanagh et al., 2004; Link, 2010; Niiranen et al., 2012). However, their application has not yet become as an integral part of the modelling process.

The more tests a model passes, the more confident modellers become in its predictions (Rykiel, 1996). In the present paper, we propose an ordered suite of complementary analyses covering various aspects of data properties related to their use in static ecosystem models such as Ecopath (Christensen and Walters, 2004; Christensen et al., 2008). We call these analyses the "DataReli" toolbox for "Data Reliability checking" toolbox. The analyses entering the DataReli toolbox were selected on three criteria: (i) their ease of implementation; (ii) their complementarity, i.e. they cover several integration levels (from single ecosystem 
6

components to whole ecosystem; and (iii) that they guarantee model long-term applications.

The DataReli toolbox is thus conceptualized in the sense of fulfilling a list of basic prerequisites with regard to data reliability common to all ecosystem models and some more specific to the scope for which the model was designed. Three complementary analyses were chosen: (i) the pedigree index (Pauly et al., 2000), which is designed to evaluate whether a model is based on extensive field sampling performed within the boundaries of the system during specific dates; (ii) the "PREBAL" or prebalancing analysis (Link, 2010), which assesses whether data are coherent to the system level by respecting some basic laws, rules and principles of ecosystem ecology; (iii) a sensitivity analysis that determines the robustness of commonly derived model outputs, namely Mixed Trophic Impacts (MTIs) (Ulanowicz and Puccia, 1990), to small variations in input data values (Rochette et al., 2009). This sensitivity analysis is useful to strengthen identification of major connections (pairwise interactions between ecosystem components, and energy pathways) within a steady-state ecosystem. The present study aims at presenting the DataReli toolbox and ensuring its full transferability to all future potential users through a concrete application to an existing Ecopath model. Input data reliability is assessed for the model of the French continental shelf of the Bay of Biscay food web (Lassalle et al., 2011). The model under study was developed for studying the ecological roles played by top predators and small pelagics in the continental shelf food web of the Bay of Biscay (Lassalle et al., 2012) and for ecosystem-based assessment of anthropogenic effects (Lassalle et al., 2014).

2. Materials and Methods

\subsection{Study area}

The Bay of Biscay is a large gulf in the Northeast Atlantic located off the western coast of France and the northern coast of Spain, between 48.5 and $43.5^{\circ} \mathrm{N}$ and 8 and $3^{\circ} \mathrm{W}$ (Fig. 1). The 

compartment:

114 system: other mortality. compartment:

ECOPATH model example for the Bay of Biscay was restricted to middle-depth continental shelf, between the 30-m and 150-m isobaths, in divisions VIIIa and b of the International Council for the Exploration of the Sea (ICES; www.ices.dk). The surface area represented by the model was about $102,585 \mathrm{~km}^{2}$.

\subsection{The Ecopath method and the Bay of Biscay application}

The mass-balance model of the French Bay of Biscay continental shelf food web was constructed using Ecopath with Ecosim 6 (EwE; Christensen and Walters, 2004; Christensen et al., 2008). Successive research programs in this region led to the collection of a significant amount of local data on various aspects of the ecosystem. Combining this information through the construction of a EwE model helped to quantify flows between the different elements of this aquatic exploited ecosystem at a specific point in time. The Ecopath model was originally proposed by Polovina (1984) and has been combined with routines for network analysis (Ulanowicz, 1986). The parameterization of an Ecopath model is based on satisfying two "'master' equations. The production equation describes the production term for each compartment (species or group of species with similar ecotrophic roles) included in the

Production $=$ fishery catch + predation mortality + net migration + biomass accumulation +

where "Other mortality" includes natural mortality factors such as mortality due to senescence, diseases, etc.

The consumption equation expresses the principle of conservation of matter within a

Consumption $=$ production + respiration + unassimilated food. 
115 The formal expressions of the above equations can be written as follows for a group $i$ and its

116 predator $j$ :

$B_{i} \times\left(\frac{P}{B}\right)_{i}=Y_{i}+\sum_{j}\left(B_{j} \times\left(\frac{Q}{B}\right)_{j} \times D C_{j i}\right)+E x_{i}+\operatorname{Bacc}_{i}+B_{i}\left(1-E E_{i}\right) \times\left(\frac{P}{B}\right)_{i}$

118 and

$B_{i} \times\left(\frac{Q}{B}\right)_{i}=B_{i} \times\left(\frac{P}{B}\right)_{i}+R_{i}+U_{i}$

120 where the main input parameters are biomass density $\left(B\right.$, here in $\mathrm{kg} \mathrm{C} \cdot \mathrm{km}^{-2}$ or tons $\left.\cdot \mathrm{km}^{-2}\right)$,

121 production rate $\left(P / B\right.$, year $\left.{ }^{-1}\right)$, consumption rate $\left(Q / B\right.$, year $\left.{ }^{-1}\right)$, proportion of $i$ in the diet of $j$

$122\left(D C_{j i} ; D C=\right.$ diet composition $)$, net migration rate $\left(E x\right.$, year $\left.^{-1}\right)$, biomass accumulation $($ Bacc,

123 year $\left.{ }^{-1}\right)$, total catch $\left(Y ; \mathrm{kg} \mathrm{C} \cdot \mathrm{km}^{-2} \cdot \mathrm{year}^{-1}\right.$ or tons $\cdot \mathrm{km}^{-2} \cdot \mathrm{year}^{-1}$; fisheries data are not compulsory

124 in Ecopath), respiration $\left(R ; \mathrm{kg} \mathrm{C} \mathrm{km}^{-2} \cdot\right.$ year $^{-1}$ or tons $\cdot \mathrm{km}^{-2} \cdot$ year $\left.^{-1}\right)$, unassimilated food rate $(U)$

125 and ecotrophic efficiency (EE; amount of species production used within the system). The

126 "other mortality" term, $M 0$, is internally computed from:

$M 0_{i}=B_{i}\left(1-E E_{i}\right) \times\left(\frac{P}{B}\right)_{i}$

128 Ecopath requires input of three parameters [biomass $(B)$, production/biomass $(P / B)$,

129 consumption/biomass $(Q / B)$ ] for every defined functional group in the system (Christensen et

130 al., 2005). From these three parameters, one can calculate the fourth main parameter required

131 for balancing, ecotrophic efficiency $(E E)$, which is the most difficult to measure. The final

132 two input components that must be entered into the model for every functional group are diet

133 composition and fisheries removals.

134 Thirty-two functional groups were included in the model: two seabird groups, five marine

135 mammal, nine fish, eight invertebrate (including two cephalopods), three zooplankton, two

136 primary producer, and one bacteria group, as well as discards from commercial fisheries and

137 pelagic detritus. The Bay of Biscay supports a multispecies, multifleet fishery with a large

138 diversity of species caught by a wide range of fishing gears primarily operated from French 
and Spanish ports (Daurès et al., 2009). As the main purpose of the pre-existing model was to

140 study general ecosystem properties, fishing activities were included as a single fleet.

141 Parameter values, diet composition and flow diagram of the Bay of Biscay Ecopath model can

142 be found in Appendix A. Further information on this model is available in Lassalle et al.

143 (2011).

144

$145 \quad 2.3$ Exploring model uncertainties through a three-step procedure

$146 \quad$ 2.3.1 Pedigree index

147 For Ecopath results to be meaningful, model parameters need to be based on information

148 specific to the study area. In Ecopath, the pedigree (Funtowicz and Ravetz, 1990) routine

149 allows marking/categorizing the data origin of each single input using pre-defined tables (see

150 Appendix B); the key criterion being that inputs from local data have the best confidence and

151 the highest level in the scale (Christensen et al., 2005).

152 When these choices are made for each single input value, an overall pedigree of the model is

153 calculated as the average of the individual pedigree values (Pauly et al., 2000) and ranges

154 from 0 (i.e. low precision information) to 1 (i.e. data and parameters fully rooted in local

155 data). A four-category scale was proposed by Morissette (2007): <0.2, 0.2-0.399, 0.4-0.599,

$156 \geq 0.6$; the last category being termed "very high pedigree". This overall pedigree $\tau$ is then very

157 useful for comparison with other models (Morissette, 2007). It is calculated as follows:

$158 \tau=\sum_{i=1}^{n} \frac{\tau_{i, p}}{n}$

159 where $\tau_{i, p}$ is the pedigree index value for functional group $i$ and parameter $p$ for each of the $n$

160 living groups in the ecosystem; $p$ can represent either $B, P / B, Q / B, Y$ or the diet composition,

$161 D C$.

162 2.3.2 PREBAL 
163 The pre-balancing (PREBAL) method outlined in Link (2010) was designed to assess the

164 model structure and data quality before mass balancing and/or dynamic simulations (e.g.

165 Ecosim module) are performed. From the data perspective, the method allows evaluation of

166 their ecological cohesiveness despite the natural discrepancies that occur when using myriad

167 data sources measured across varying scales.

168 Link (2010) provides a set of guidelines/diagnostics to both model developers and reviewers

169 as a form of a "checklist" that can be tested through graphical representations. These

170 diagnostics were based on essential laws, rules and principles of ecosystem ecology. (i) The

171 primary production of an ecosystem forms the basis from which all other productivity, and

172 hence energy flows, are derived (Lindeman, 1942; Odum, 1956; Pauly, 1980; Ulanowicz,

173 1986; Pauly and Christensen, 1995). (ii) A decline in biomass from primary producers to top

174 consumers is expected as it reflects the lower abundance of larger-sized organisms at upper

175 trophic levels (Sheldon et al., 1972; Thiebaux and Dickie, 1993). There should be more total

176 biomass of prey in ecosystems than biomass of predators (Lindeman, 1942; Jennings et al.,

177 2001; Jennings and Mackinson, 2003; Brose et al., 2006). (iii) The relative allocation of

178 biomasses among habitats, or functional groups, is an appropriate indicator of major pathways

179 of energy flows within an ecosystem (Lindeman, 1942; Fulton et al., 2005; Link, 2005).

180 Link's diagnostics of food-web models are divided into five general classes: biomasses across

181 taxa and trophic levels; biomass ratios; vital rates across taxa and trophic levels $(P / B, Q / B$ and

$182 R / B$ ); vital rate ratios; and total production and removals (Link, 2010). When checking for

183 departures from the proposed guidelines, particular attention should be paid to taxa at the two

184 extremes of the food web: bacteria and primary producers, and homeotherms top predators.

185 Indeed, the first have lower standing stock biomasses than their terrestrial counterparts

186 (Steele, 1985; Link et al., 2005). The second tend to have lower production by higher

187 metabolic and hence consumptive demands per unit body mass (Peters, 1983) than 
poikilotherms. The maintenance of constant body temperature requires continuous provision

189 of energy by homeotherms. As such, bacteria, primary producers and homeotherms top

190 predators could present systematic departures from the expected trends or could not meet the

191 intended values. Among the set of criteria proposed by Link (2010), the most suitable to the

192 present model evaluation are retained and detailed in Table 1. If one or several diagnostics are

193 not met, initial estimates should be revisited before any Ecopath model balancing or tuning is

194 executed. Link (2010) provided full details of what a departure is symptomatic of. If sufficient

195 information is not available for revision, modellers or reviewers should carefully

196 acknowledge of potential model gaps and their consequences when interpreting model

197 outputs.

$198 \quad$ 2.3.3 A sensitivity analysis on the mixed trophic impacts

199 The mixed trophic impact (MTI) matrix quantifies the direct and indirect trophic impacts of 200 each functional group on (the biomass of) all other functional groups (Ulanowicz and Puccia, 201 1990) at constant trophic structure. MTIs are central in addressing diverse research questions 202 such as the importance of the competition between fisheries and marine mammals (Morissette 203 et al., 2013), the identification of keystone species in food webs (Libralato et al., 2006) or the 204 determination of structural ecosystem changes resulting from exploitation (Cury et al., 2005). 205 Quantifying the confidence that can be placed on these model outputs would provide valuable 206 information in the context of the management of living marine resources. Robust MTIs are 207 defined here as those invariant in their sign, not in their magnitude, indicating potential 208 direction of changes.

209 Rochette et al. (2009) extended the estimation of uncertainty on qualitative models proposed 210 by Dambacher et al. (2002) to quantitative ecosystem data. This method was applied on MTI

211 estimations. The elements of the MTI matrix $m_{i j}$ are calculated as the product of the net 212 impacts $q_{i j}$ of all possible pathways in the food web that link the functional groups $i$ and $j$. 
213 Negative $m_{i j}$ values indicate prevalence of predator effects (top-down effects) while positive

214 values indicate prevalence of prey effects (bottom-up effects). The net impact of $i$ on $j$,

215 denoted $q_{i j}$, is given by the difference between positive effects $d_{j i}$ (quantified by the fraction of

216 prey $i$ in the diet of predator $j$; biomass creation), and negative effects $f_{i j}$ (evaluated as the

217 fraction of total consumption of $j$ used by predator $i$; biomass removal). The compartment $i$ is

218 alternatively a prey then a predator:

$219 q_{i j}=d_{j i}-f_{i j}$

220 To evaluate the sensitivity of the signs of the MTI responses $\left(m_{i j}\right)$ to small changes in the 221 original $q_{i j}$ values, 5000 Q matrices are created by drawing $q_{i j}$ values from independent 222 uniform distributions defined by original $q_{i j} \pm 20 \%$ (Richardson et al., 2006). The sample of Q 223 matrices is then used to calculate $m_{i j}$ values for each pairwise intersection, record their sign 224 and estimate the percentage of $m_{i j}$ values with the same sign as in the original MTI matrix 225 (S $\left.\mathrm{S}_{\mathrm{MTI}}\right)$ (see Fig. 3 in Rochette et al. (2009) and Nelva Pasqual (2014)). Results are 226 summarized into one matrix recording the sign of the original $m_{i j}$ values and the $\mathrm{S}_{\mathrm{MTI}}$ 227 percentages that are categorized into four classes: $[0 ; 50]] 50 ; 75]] 75 ; 95$,$] and ] 95 ; 100]$. 228 The original Q matrix on which the sensitivity analysis is performed, then the resulting MTI matrix, is slightly different from the one currently implemented in Ecopath (see Appendix C).

230 (i) Flows to detritus (i.e. non-assimilated food, natural mortality), as well as fishery, are 231 considered in the total mortality fluxes of each component in the calculation of the 232 interactions $d_{j i}$. Detritus are considered as false predators having kind of a diet $\left(d_{d e t, i}=\right.$ flow to 233 detritus), but without having a negative direct impact on its "preys": $f_{d e t, i}=0$. Fishery and 234 discards are considered as true predators. Both matrices D and F are thus built including 235 detritus and fishery and prepared so that $\sum_{i} d_{j i}=1$ and $\sum_{j} f_{j i}=1$. (ii) In the calculation of 236 the original MTI matrix, a second difference relates to the diagonal values $q_{i i}$ of the net impact matrix Q that represent intra-effects of a specific compartment. These $d_{i i}$ values are set to -1 . 
Intra-effects are intra-specific competition for space and resources particularly for primary

239 producers, intra-component predation, and links with the outside system such as external

240 recruitment or consumption of species from outside the system (Puccia and Levins, 1985).

241 (iii) The resulting net impact matrix Q ( D - F) is inverted according to Dambacher et al.

242 (2002), the inverted matrix being the original MTI matrix.

243 The calculation of this alternative MTI matrix and the sensitivity analysis performed on it are

244 not part of the distributed EwE 6 software package. The sensitivity analysis is performed with

245 the R software and the code is provided in Appendix D. Further technical information can

246 also be found in Rochette et al. (2009) and on request to the corresponding author of the

247 present paper.

249 3. Results

250 Application of the "DataReli" toolbox to the present case study indicates a model based on 251 data of rather good quality, quantity and coherence at the ecosystem scale.

252 The overall pedigree index for the Bay of Biscay continental shelf food-web model is 0.60 ;

253 biomass, diet composition and catches having higher entries on average than $P / B$ and $Q / B$

254 (Table 2). By comparison with other functional groups, cephalopods are noticeably described 255 with data of globally low confidence and thus appear understudied in the Bay of Biscay 256 continental shelf food web.

257 PREBAL diagnostics applied to our case study show general coherent decompositions of 258 parameters with increasing trophic levels (TLs) (Fig. 2). The ecological cohesiveness of the 259 data is particularly demonstrated for vital rates, and total production and removals.

260 Nevertheless, unexpected punctual departures from rules of thumb are noted (in bold, Table

261 1). (i) The biomass of surface-feeder seabirds is considerably below the trend line of biomass 262 allocation across TLs (Fig. 2). This functional group combines a very small biomass with an 
intermediate TL of 3.71, the maximum TL being 5.18 for dolphins. The biomass estimate of

264 these marine birds is based on sampling of high precision (maximum pedigree index value of 1). By contrast, their diet compositions correspond to general knowledge about this issue and are thus far less reliable. (ii) In the biomass ratios diagnostic, the biomass of zooplankton $\left(1652 \mathrm{~kg} \mathrm{C} \mathrm{km}^{-2}\right.$ year $\left.^{-1}\right)$ is twice that of benthos $\left(730.5 \mathrm{~kg} \mathrm{C} \mathrm{km}^{-2}\right.$ year $\left.{ }^{-1}\right)$ and contradicts the rule of thumb that points to the equitable apportionment of biomass for comparable trophic

269 level groups in major pathways of trophic flows (Fig. 3). Both biomasses are classified in the pedigree routine as "sampling-based" but only zooplankton is considered of high resolution thus indicating lower confidence in the benthos data. Nonetheless, the sensitivity analysis on

272 the MTI shows a high confidence in the sign of the effect of benthos on other ecosystem 273 components. More than $85 \%$ of their intersections have a $S_{M T I}$ superior to $95 \%$ (Fig. 4). (iii) 274 As expected by Link (2010), groups at the two extremes of the Bay of Biscay continental 275 shelf food web, i.e. primary producers, and marine mammals and seabirds, present out-of276 trend values compared to their trophic position and should be excluded when interpreting 277 most diagnostics. For example, high-TL homeotherms (groups 1-7) tend to have a lower 278 production, higher consumption and respiration compared to poikilotherms (Fig. 2).

279 The sensitivity analysis $S_{\text {MTI }}$ percentages never reach a homogeneous $100 \%$ confidence, but 280 results show that $87 \%$ of the pairwise intersections in the original MTI matrix have a sign 281 with a confidence percentage superior to $95 \%$ (Fig. 4). This means that, for a given 282 intersection, more than 4750 over 5000 possible configurations of the food web lead to a sign 283 identical to the one reported in the original MTI matrix. Two intersections have an extremely 284 undetermined sign $\left(\mathrm{S}_{\mathrm{MTI}} \sim 35 \%\right)$ : a small increase of long-finned pilot whales and piscivorous 285 demersal fish (group 6 and 8 respectively) causes an effect on the Harbour porpoises 286 (Phocoena phocoena; group 8) that may be opposed to the original MTI matrix. Most 287 interactions with a $S_{\mathrm{MTI}}$ around $50 \%$ are related to the upper part of the food web (seabirds, 
marine mammals, and demersal and pelagic fish), suggesting more uncertain top-down impacts than bottom-up effects. The Atlantic mackerel (Scomber scombrus), when considered as an impacting group (read along row 12), presents the highest frequency of effects with a $\mathrm{S}_{\mathrm{MTI}}$ inferior to $95 \%$ (30\% of them) and the lowest overall $\mathrm{S}_{\mathrm{MTI}}$ value which is equal to $91 \%$. For cephalopods (groups 17 and 18), uncertain input data revealed by the pedigree routine do not translate into very uncertain effects in the sensitivity analysis, even when considering cephalopods as an impacting or an impacted group. As such, improving data precision for this compartment would not impact our interpretation of ecosystem functioning.

\section{Discussion}

The "DataReli" toolbox is proposed to modellers to ensure the best congruence between the reliability of the input data used during model construction and the purposes for which an ecosystem model, in particular EwE, was intended. From a general perspective, capturing potential problems in data reliability should prevent the use of this model to address given research or management questions. Nonetheless, the decision can be taken to correct the "weak" parameters for improved ecological integrity and validity (e.g. Byron et al., 2011). (i)

304 Corrections of parameters should be preferentially envisaged when modelling data-rich environments. A meta-analysis of $50 \mathrm{EwE}$ models showed that few models exhibited a very high pedigree ( $10 \%$ have a pedigree higher than 0.60 , with the maximum value being 0.65 ) (Morissette, 2007). As such, an overall pedigree index $(\tau)$ in the medium-high range as

308 defined by Morissette (2007), i.e. between 0.4 and 1, likely testifies to an ecosystem 309 benefiting from a sufficient amount of data to allow revision of the model. The Bay of Biscay continental shelf food-web model falls into the highest range of this categorization. This high

311 comparative pedigree value is even more meaningful when considering that in the present

312 work the input data should have described a thousand $\mathrm{km}^{2}$ of a system open to the Atlantic 
Ocean. (ii) For those models with $\tau$ above 0.4 , a closer look at the pedigree routine, i.e. values

314 by parameters and compartments, and the PREBAL analysis would help to prioritize parameters needing improvement. We suggest investing extra effort particularly on parameters with low pedigree value that lead to noticeable departure from PREBAL diagnostics. Moreover, their position regarding an expected trend line (threshold) across 318 trophic levels (pathways) gives the main direction for revisiting those initial estimates. In the present case study, deviations from the PREBAL trend lines, or threshold values, are more related to modeller choices or to underlying assumptions of the modelling software than to poor quality data or ecological incoherencies in the model. As an example, surface-feeder seabird biomass does not fit with the general biomass allocation pattern in ecosystems (moderate to sharp decline across TLs) (e.g. Gascuel, 2005; Gascuel et al., 2009). Given the 324 high quality of the biomass estimate, this below-trend value could be explained by an underestimation of the TL. Kittiwakes and gulls have a substantial part of their diet coming 326 from discarded organisms (Arcos and Oro, 2002), which are considered in Ecopath as dead 327 material with a TL arbitrarily set to unity (Christensen and Pauly, 1992). When calculating the 328 TL of discards as the weighted average of discarded fish TL, the trophic position of seabirds 329 markedly increases from 3.72 to 4.49. Including microbial loop in Ecopath models remains a 330 challenging task (Pavés and González, 2008). Here, the bacterial P/R ratio greater than 1 is 331 partly related to lack of data regarding the fraction of food not assimilated by bacteria. Higher 332 biomass of zooplankton compared to benthos is partly driven by differences in data quality.

333 Benthos biomass was extrapolated from a study covering a small fraction of the Bay of

334 Biscay continental shelf known as the "Grande Vasière" mudflat while zooplankton biomass 335 was estimated from large-scale campaigns (Lassalle et al., 2011). (ii)' For Ecopath models of 336 no overall acceptable quality $(\tau<0.4)$, we recommend stopping the DataReli procedure at this 337 point. They should be combined with other modelling approaches before deriving any 
conclusions (Metcalf, 2010; Gårdmark et al., 2012; Lassalle et al., 2014). (iii) In terms of

339 sensitivity analysis, marked responses of model predictions (here MTI) to small variations in

340 the input values must preferentially lead to restrictions in the model applications compared to

341 corrections of parameter estimates. The Bay of Biscay continental shelf food-web model was

342 originally designed to provide a holistic understanding of the ecosystem's structure and

343 functioning with a special emphasis on the ecological roles played by top predators and small

344 pelagics (Lassalle et al., 2011; Lassalle et al., 2012). Bottom-up processes were demonstrated

345 to play a significant role in the population dynamics of upper-trophic levels and in the global

346 structuring of this marine ecosystem (Lassalle et al., 2011). In the context of the marine

347 strategy framework directive (MSFD; http://ec.europa.eu; Directive 2008/56/EC),

348 mesozooplankton abundance, diversity and/or biomass were identified as reliable indicators

349 of Bay of Biscay continental shelf changes. Both propositions regarding the functioning and

350 monitoring of this ecosystem were partly based on the proportion of positive MTI values

351 when a compartment is considered as an impacting group (Libralato et al., 2006). These

352 propositions are thus reinforced by the high confidence percentages on the signs of effects

353 noted in the present sensitivity study.

354

355 5. Conclusion

356 In conclusion for the case study, a general level of input data reliability that is satisfying with

357 regard to the model applications has been achieved. Recently, Essington and Plagányi (2014)

358 conducted a comparative study on the capacity of 18 ecosystem models for evaluating the

359 ecosystem effects of forage fish fisheries. The Bay of Biscay Ecopath model was also

360 positively evaluated in terms of time and spatial matching to stocks and of data

361 representativeness and availability. However, we believe improvements could be investigated 
362 in the future, particularly on the parameterization of pelagic and benthic cephalopods, and 363 mackerel.

364

365 Acknowledgments

366 This research has been mainly supported by the project DEVOTES (DEVelopment Of

367 innovative Tools for understanding marine biodiversity and assessing good Environmental

368 Status) funded by the European Union under the 7th Framework Programme, 'The Ocean for

369 Tomorrow' Theme (grant agreement no. 308392; www.devotes-project.eu). 
Figure captions

372 Fig. 1. Study area of the Bay of Biscay continental shelf and locations of the main rivers

373 flowing into it. The shaded area corresponds to the French part of the continental shelf, and

374 represents the spatial extent of the Ecopath model example.

Fig. 2. Vital rates across taxa and trophic levels for the Bay of Biscay continental shelf foodweb model. Trend lines are also given. $B$ : biomass, $Q$ : consumption, $P$ : production, $R$ : respiration, and ratios accordingly. Homeotherms are marked with as asterisk. Trophic levels (TL) increase from left to right.

Fig. 3. Biomass ratios across major (A) predator/prey interactions and (B) pathways of trophic flows for the Bay of Biscay continental shelf food-web model. (A) B.Inv: benthic invertebrates, D.Pisc: demersal and medium pelagic piscivores, MMB: marine mammals and birds, Phy: phytoplankton, SP: small pelagics, Z: zooplankton. (B) Ben: benthos, Dem: demersal, Pel: pelagic, Z: zooplankton.

Fig. 4. Probability of obtaining a sign identical to the one reported in the original MTI matrix when applying small variations to the original net impact Matrix Q for the Bay of Biscay continental shelf food-web model. The sign is the one of the original MTI matrix. Signs (-) correspond to negative effects of an increase of the components in rows on the components in

391 column. Conversely, signs (+) represent positive effects of an increase of the components in

392 rows on the components in columns. Light grey squares: effects with high confidence

393 percentage (>95\%); medium grey squares: [95-75[; dark grey squares: [75-50[; dark squares:

$394<50 \%$ (this means the average sign from the sensitivity analysis is opposed to the one of the 395 original MTI matrix). 
Table 1. Food-web model diagnostics used for the evaluation of the Bay of Biscay continental shelf food-web model according to Link (2010).

Rules of thumb for their appropriate application are presented. Status informs on whether these rules are generally met for the present model. Small to moderate departures to these rules are listed in Remarks. Those given in plain text are the discrepancies expected by Link (2010) for most ecosystems and those in bold are the discrepancies specific to the present model. $B$ : biomass, $Q$ : consumption, $P$ : production, PP: primary producers, $R$ : respiration, TL: trophic level.

\begin{tabular}{|c|c|c|c|}
\hline Class of diagnostics & Rules of thumb & Status & Remarks \\
\hline$B$ across taxa and TLs & a range of 5-7 orders of magnitude & $\mathrm{OK}$ & / \\
\hline \multirow{2}{*}{ (detritus omitted) } & slope $\sim 5-10 \%$ decline along increasing TLs & $\mathrm{OK}$ & / \\
\hline & few taxa notably above or below slope-line & $\mathrm{OK}$ & $B$ of surface-feeder seabirds too small \\
\hline \multirow[t]{2}{*}{$B$ ratios } & Predator $B$ less than that of their prey & OK & $\begin{array}{l}B \text { of phytoplankton less than B of } \\
\text { zooplankton }\end{array}$ \\
\hline & $\begin{array}{l}\text { Equitable apportionment of } B \text { for comparable } \\
\text { TL groups in major pathways of trophic flow }\end{array}$ & $\sim$ & $\begin{array}{l}\text { Higher } B \text { of zooplankton compared }(\sim \mathrm{x} 2) \\
\text { to benthos }\end{array}$ \\
\hline $\begin{array}{l}\text { Vital rates across taxa } \\
\text { and TLs }\end{array}$ & $\begin{array}{l}\text { Decline of } Q / B, P / B \text { and } R / B \text { along increasing } \\
\text { TLs }\end{array}$ & OK & Exception for homeotherms at upper TLs \\
\hline (detritus omitted) & A few taxa notably above or below slope-line & $\mathrm{OK}$ & Exception for homeotherms at upper TLs \\
\hline \multirow[t]{4}{*}{ Vital rate ratios } & Predator vital rate less than that of their prey & OK & Exception for homeotherms at upper TLs \\
\hline & $P / B$ across taxa less than $P / B$ of $P P$ & OK & 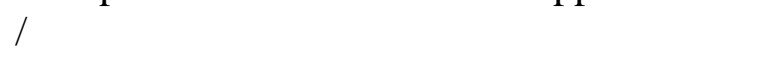 \\
\hline & $P / Q$ less than 1 for each taxa & OK & / \\
\hline & $P / R$ less than 1 for each taxa & $\mathrm{OK}$ & Exception for bacteria \\
\hline \multirow[t]{5}{*}{ Total $P$ and removals } & $\begin{array}{l}\text { Total, scaled } P, Q \text { and } R \text { decline along } \\
\text { increasing TLs }\end{array}$ & OK & Exception for homeotherms at upper TLs \\
\hline & $Q$ exerted on a taxa less than its own $P$ & OK & / \\
\hline & $Q$ by a taxa greater than its own $P$ & OK & / \\
\hline & Total human removals less than $P$ of a taxa & OK & / \\
\hline & $\begin{array}{l}\text { Total human removals less than } Q \text { exerted on } \\
\text { a taxa }\end{array}$ & OK & / \\
\hline
\end{tabular}


Table 2. Categorizing data origins for major input parameters for the Bay of Biscay continental shelf food-web model. This classification is

based on pre-defined scales, with higher values representing a greater confidence (Christensen et al., 2005) (see Appendix B).* represents when the maximum index value is given, i.e. 6 for $B$, diet and catches and 8 for $P / B$ and $Q / B$. Blank cells mean that no such input parameter is required for the functional group, e.g. $P / B$ or $Q / B$ are not filled for non-living compartments such as detritus and discards, or that the functional group is not exploited. Default confidence intervals (C.I.) assigned to data based on their origin are given and are expressed as $+/-\%$, with n.a. for missing parameters.

\begin{tabular}{|c|c|c|c|c|c|c|c|c|c|}
\hline Group name & $B$ & C.I. ${ }_{\underline{B}}$ & $\mathrm{P} / B$ & C.I. $P / B$ & $Q / B$ C.I. $Q / B$ & Diet & C.I. Diet & Catches & C.I. Catches $_{\text {. }}$ \\
\hline Plunge and pursuit diver seabirds & $6^{*}$ & 10 & 2 & 90 & $4 \quad 50$ & 3 & 80 & & \\
\hline Surface-feeder seabirds & $6 *$ & 10 & 2 & 90 & 50 & 3 & 80 & & \\
\hline Striped dolphins & $6^{*}$ & 10 & 3 & 80 & 50 & $6^{*}$ & 30 & & \\
\hline Bottlenose dolphins & $6^{*}$ & 10 & 3 & 80 & 50 & $6^{*}$ & 30 & & \\
\hline Common dolphins & $6^{*}$ & 10 & 3 & 80 & 50 & $6^{*}$ & 30 & 5 & 30 \\
\hline Long-finned pilot whales & $6^{*}$ & 10 & 3 & 80 & 50 & $6^{*}$ & 30 & & \\
\hline Harbour porpoises & $6 *$ & 10 & 3 & 80 & 50 & $6^{*}$ & 30 & 5 & 30 \\
\hline Piscivorous demersal fish & $6^{*}$ & 10 & 4 & 50 & 50 & 5 & 40 & $6^{*}$ & 10 \\
\hline Pisicvorous and benthivorous demersal fish & $6^{*}$ & 10 & 4 & 50 & 50 & 5 & 40 & $6^{*}$ & 10 \\
\hline Suprabenthivorous demersal fish & $6^{*}$ & 10 & 4 & 50 & 50 & 5 & 40 & $6^{*}$ & 10 \\
\hline Benthivorous demersal fish & $6^{*}$ & 10 & 4 & 50 & 50 & 5 & 40 & $6^{*}$ & 10 \\
\hline Mackerel & 4 & $50-80$ & 4 & 50 & 50 & $6^{*}$ & 30 & $6^{*}$ & 10 \\
\hline Horse mackerel & 4 & $50-80$ & 4 & 50 & 50 & $6^{*}$ & 30 & $6^{*}$ & 10 \\
\hline Anchovy & $6^{*}$ & 10 & 4 & 50 & 50 & $6^{*}$ & 30 & $6^{*}$ & 10 \\
\hline Sardine & $6^{*}$ & 10 & 4 & 50 & 50 & $6^{*}$ & 30 & $6^{*}$ & 10 \\
\hline Sprat & $6^{*}$ & 10 & 4 & 50 & 50 & $6^{*}$ & 30 & & \\
\hline Benthic cephalopods & 1 & n.a. & 3 & 80 & 80 & 4 & 50 & $6^{*}$ & 10 \\
\hline Pelagic cephalopods & 1 & n.a. & 3 & 80 & 80 & 4 & 50 & $6^{*}$ & 10 \\
\hline
\end{tabular}


Carnivorous benthic invertebrates

Necrophagous benthic invertebrates

Sub-surface deposit feeder inv.

Surface suspension and deposit feeder inv.

Benthic meiofauna

Suprabenthic invertebrates

Macrozooplankton ( $\geq 2 \mathrm{~mm})$

Mesozooplankton $(0.2-2 \mathrm{~mm})$

Microzooplankton $(\leq 0.2 \mathrm{~mm})$

Bacteria

Large phytoplankton $(\geq 3 \mu \mathrm{m})$

Small phytoplankton $(<3 \mu \mathrm{m})$

Discards

Pelagic detritus

$$
\begin{array}{ll}
5 & 40 \\
5 & 40 \\
5 & 40 \\
5 & 40 \\
5 & 40 \\
5 & 40 \\
6^{*} & 10 \\
6^{*} & 10 \\
6^{*} & 10 \\
6^{*} & 10 \\
6^{*} & 10 \\
6^{*} & 10
\end{array}
$$


466 Arcos, J.M., Oro, D., 2002. Significance of fisheries discards for a threatened Mediterranean seabird, the Balearic shearwater Puffinus mauretanicus. Marine Ecology Progress Series 239, 209-220.

469 Brose, U., Jonsson, T., Berlow, E.L., Warren, P., Banasek-Richter, C., Bersier, L.-F., 470 Blanchard, J.L., Brey, T., Carpenter, S.R., Cattin Blandenier, M.-F., Cushing, L., Dawah, 471 H.A., Dell, T., Edwards, F., Harper-Smith, S., Jacob, U., Ledger, M.E., Martinez, N.D., 472 Memmott, J., Mintenbeck, K., Pinnegar, J.K., Rall, B.C., Rayner, T.S., Reuman, D.C., Ruess, 473 L., Ulrich, W., Williams, R.J., Woodward, G., Cohen, J.E., 2006. Consumer-resource body474 size relationships in natural food webs. Ecology 87, 2411-2417.

475 Browman, H.I., Cury, P., Hilborn, R., Jennings, S., Lotze, H.K., Mace, P.M., Murawski, S., 476 Pauly, D., Sissenwine, M., Stergiou, K.I., Zeller, D., 2004. Perspectives on ecosystem-based 477 approaches to the management of marine resources. Marine Ecology Progress Series 274, $478 \quad 269-303$.

479 Byron, C., Link, J., Costa-Pierce, B., Bengtson, D., 2011. Calculating ecological carrying 480 capacity of shellfish aquaculture using mass-balance modeling: Narragansett Bay, Rhode 481 Island. Ecological Modelling 222, 1743-1755.

482 Christensen, V., Pauly, D., 1992. ECOPATH II - a software for balancing steady-state 483 ecosystem models and calculating network characteristics. Ecological Modelling 61, 169-185.

484 Christensen, V., Walters, C.J., 2004. Ecopath with Ecosim: methods, capabilities and 485 limitations. Ecological Modelling 172, 109-139.

486 Christensen, V., Walters, C.J., Pauly, D., 2005. Ecopath with Ecosim: a user's guide. Fisheries 487 Centre, University of British Columbia, Vancouver, Canada. 154 pp. 
Christensen, V., Walters, C.J., Pauly, D., Forrest, R., 2008. Ecopath with Ecosim version 6.

489 User guide - November 2008. Lenfest Ocean Futures Project 2008. Fisheries Centre,

490 University of British Columbia, Vancouver, Canada. 235 pp.

491 Cury, P.M., Shannon, L.J., Roux, J.P., Daskalov, G.M., Jarre, A., Moloney, C.L., Pauly, D., 492 2005. Trophodynamic indicators for an ecosystem approach to fisheries. ICES Journal of 493 Marine Science 62, 430-442.

494 Dambacher, J.M., Li, H.W., Rossignol, P.A., 2002. Relevance of community structure in 495 assessing indeterminacy of ecological predictions. Ecology 83, 1372-1385.

496 Dame, J.K., Christian, R.R., 2006. Uncertainty and the use of network analysis for ecosystem497 based fisheries management. Fisheries 31, 331-341.

498 Daurès, F., Rochet, M.-J., Van Iseghem, S., Trenkel, V.M., 2009. Fishing fleet typology, 499 economic dependence, and species landing profiles of the French fleets in the Bay of Biscay, 500 2000-2006. Aquatic Living resources 22, 535-547.

501 Essington, T.E., Plagányi, É.E., 2014. Pitfalls and guidelines for "recycling” models for 502 ecosystem-based fisheries management: evaluating model suitability for forage fish fisheries.

503 ICES Journal of Marine Science 71, 118-127.

504 Fulton, A.E., 2010. Approaches to end-to-end ecosystem models. Journal of Marine Systems $50581,171-183$.

506 Fulton, E.A., Smith, A.D.M., Johnson, C.R., 2003. Effect of complexity on marine ecosystem 507 models. Marine Ecology Progress Series 253, 1-16.

508 Fulton, E.A., Smith, A.D.M., Punt, A.E., 2005. Which ecological indicators can robustly 509 detect effects of fishing? ICES Journal of Marine Science 62, 540-551.

510 Funtowicz, S.O., Ravetz, J.R., 1990. Uncertainty and quality in science for policy. Kluwer 511 Academic Publishers. 229 pp. 
512 Gårdmark, A., Lindegren, M., Neuenfeldt, S., Blenckner, T., Heikinheimo, O., Müller-

513 Karulis, B., Niiranen, S., Tomczak, M., Aro, E., Wikström, A., Möllmann, C., 2012.

514 Biological ensemble modelling to evaluate potential futures of living marine resources.

515 Ecological Applications 23, 742-754.

516 Gardner, R.H., O’Neill, R.V., 1983. Parameter uncertainty and model predictions: a review of

517 Monte Carlo results. In: M.B. Beck, G. Straten (ed.). Uncertainty and forecasting of water

518 quality, Springer Berlin Heidelberg. pp. 245-257

519 Gardner, R.H., Cale, W.G., O'Neill, R.V., 1982. Robust analysis of aggregation error.

520 Ecology 63, 1771-1779.

521 Gascuel, D., 2005. The trophic-level based model: a theoritical approach of fishing effects on

522 marine ecosystems. Ecological Modelling 189, 315-332.

523 Gascuel, D., Tremblay-Boyer, L., Pauly, D., 2009. EcoTroph (ET): a trophic level based

524 software for assessing the impacts of fishing on aquatic ecosystems. Fisheries Centre,

525 University of Bristish Columbia, Vancouver, Canada. 82 pp.

526 Hill, S.L., Watters, G.M., Punt, A.E., McAllister, M.K., Quéré, C., Turner, J., 2007. Model

527 uncertainty in the ecosystem approach to fisheries. Fish and Fisheries 8, 315-336.

528 Jennings, S., Mackinson, S., 2003. Abundance-body mass relationships in size-structured

529 food webs. Ecology Letters 6, 971-974.

530 Jennings, S., Pinnegar, J.K., Polunin, N.V.C., Boon, T.W., 2001. Weak cross-species

531 relationships between body size and trophic level belie powerful size-based trophic

532 structuring in fish communities. Journal of Animal Ecology 70, 934-944.

533 Johnson, G.A., Niquil, N., Asmus, H., Bacher, C., Asmus, R., Baird, D., 2009. The effects of 534 aggregation on the performance of the inverse method and indicators of network analysis.

535 Ecological Modelling 220, 3448-3464. 
536 Kavanagh, P., Newlands, N., Christensen, V., Pauly, D., 2004. Automated parameter

537 optimization for Ecopath ecosystem models. Ecological Modelling 172, 141-149.

538 Kearney, K.A., Stock, C., Sarmiento, J.L., 2013. Amplification and attenuation of increased

539 primary production in a marine food web. Marine Ecology Progress Series 491, 1-14.

540 Lassalle, G., Nelva-Pasqual, J.-S., Boët, P., Rochet, M.-J., Trenkel, V.M., Niquil, N., 2014.

541 Combining quantitative and qualitative models to identify functional groups for monitoring

542 changes in the Bay of Biscay continental shelf exploited foodweb. ICES Journal of Marine

543 Science 71, 105-117.

544 Lassalle, G., Gascuel, D., Le Loc’h, F., Lobry, J., Pierce, G.J., Ridoux, V., Santos, M.B.,

545 Spitz, J., Niquil, N., 2012. An ecosystem approach for the assessment of fisheries impacts on

546 marine top-predators: the Bay of Biscay case study. ICES Journal of Marine Science 69, 925-

547938.

548 Lassalle, G., Lobry, J., Le Loc'h, F., Bustamante, P., Certain, G., Delmas, D., Dupuy, C.,

549 Hily, C., Labry, C., Le Pape, O., Marquis, E., Petitgas, P., Pusineri, C., Ridoux, V., Spitz, J.,

550 Niquil, N., 2011. Lower trophic levels and detrital biomass control the Bay of Biscay

551 continental shelf food web: implications for ecosystem management. Progress In

552 Oceanography 91, 61-75.

553 Lehuta, S., Mahévas, S., Petitgas, P., Pelletier, D., 2010. Combining sensitivity and

554 uncertainty analysis to evaluate the impact of management measures with ISIS-Fish: marine

555 protected areas for the Bay of Biscay anchovy (Engraulis encrasicolus) fishery. ICES Journal

556 of Marine Science 67, 1063-1075.

557 Libralato, S., Christensen, V., Pauly, D., 2006. A method for identifying keystone species in 558 food web models. Ecological Modelling 195, 153-171.

559 Lindeman, R., 1942. The trophic-dynamic aspect of the ecology. Ecology 23, 399-418. 
Link, J., Stockhausen, W.T., Methratta, E.T., 2005. Food web theory in marine ecosystems.

561 In: A. Belgrano, U.M. Scharler, J.A. Dunne, R.E. Ulanowicz (ed.). Aquatic food webs - an

562

563

564

565

566

567

568

569

570

571

572

573

574

575

576

577

578

579

580

581

582

583

584 ecosystem approach, Oxford University Press. pp. 98-115

Link, J.S., 2005. Translating ecosystem indicators into decision criteria. ICES Journal of Marine Science 62, 569-576.

Link, J.S., 2010. Adding rigor to ecological network models by evaluating a set of prebalance diagnostics: a plea for PREBAL. Ecological Modelling 221, 1580-1591.

Metcalf, S.J., 2010. Qualitative models to complement quantitative ecosystem models for the analysis of data-limited marine ecosystems and fisheries. Reviews in Fisheries Science 18, 248-265.

Morissette, L., 2007. Complexity, cost and quality of ecosystem models and their impact on resilience: a comparative analysis, with emphasis on marine mammals and the Gulf of St.

Lawrence. PhD Thesis, University of British Columbia, Canada. 260 pp.

Morissette, L., Christensen, V., Pauly, D., 2013. Marine mammal impacts in exploited ecosystems: would large scale culling benefit fisheries? PLoS ONE 7, e43966.

Nelva Pasqual, J.-S., 2014. Exploring estuarine ecological networks: from structure to dynamics. A synthesis and comparison of matrix approaches. PhD Thesis, University of Bordeaux 1, Bordeaux, France.

Niiranen, S., Blenckner, T., Hjerne, O., Tomczak, M., 2012. Uncertainties in a Baltic Sea food-web model reveal challenges for future projections. Ambio 41, 613-625.

Odum, H.T., 1956. Efficiencies, size of organisms, and community structure. Ecology 37, 592-597.

Pauly, D., 1980. On the interrelationships between natural mortality, growth parameters, and mean environmental temperature in 175 fish stocks. Journal du Conseil Permanent International pour l'Exploration de la Mer 39, 175-192. 
585 Pauly, D., Christensen, V., 1995. Primary production required to sustain global fisheries.

$586 \quad$ Nature 374, 255-257.

587 Pauly, D., Christensen, V., Walters, C., 2000. Ecopath, Ecosim, and Ecospace as tools for 588 evaluating ecosystem impact of fisheries. ICES Journal of Marine Science 57, 697-706.

589 Pavés, H.J., González, H.E., 2008. Carbon fluxes within the pelagic food web in the coastal 590 area off Antofagasta $\left(23^{\circ} \mathrm{S}\right)$, Chile: The significance of the microbial versus classical food 591 webs. Ecological Modelling 212, 218-232.

592 Peters, R.H., 1983. The ecological implications of body size. Cambridge University Press.

593 Pinnegar, J.K., Blanchard, J.L., Mackinson, S., Scott, R.D., Duplisea, D.E., 2005.

594 Aggregation and removal of weak-links in food-web models: system stability and recovery 595 from disturbance. Ecological Modelling 184, 229-248.

596 Polovina, J.J., 1984. Model of coral reef ecosystem I. The Ecopath model and its application 597 to French Frigate Shoals. Coral Reefs 3, 1-11.

598 Puccia, C.J., Levins, R., 1985. Qualitative modeling of complex systems: an introduction to 599 loop analysis and time averaging. Harvard University Press. 256 pp.

600 Richardson, T.L., Jackson, G.A., Ducklow, H.W., Roman, M.R., 2006. Spatial and seasonal 601 patterns of carbon cycling through planktonic food webs of the Arabian Sea determined by 602 inverse analysis. Deep Sea Research Part II: Topical Studies in Oceanography 53, 555-575.

603 Rochette, S., Lobry, J., Lepage, M., Boët, P., 2009. Dealing with uncertainty in qualitative 604 models with a semi-quantitative approach based on simulations. Application to the Gironde 605 estuarine food web (France). Ecological Modelling 220, 122-132.

606 Rykiel, E.J., 1996. Testing ecological models: the meaning of validation. Ecological 607 Modelling 90, 229-244.

608 Sheldon, R.W., Prakash, A., Sutcliffe, W.H., 1972. The size distribution of particles in the 609 ocean. Limnology and Oceanography 17, 327-340. 
610 Steele, J.H., 1985. A comparison of terrestrial and marine ecological systems. Nature 313, $611 \quad 355-358$.

612 Thiebaux, M.L., Dickie, L.M., 1993. Structure of the body-size spectrum of the biomass in 613 aquatic ecosystems: a consequence of allometry in predator-prey interactions. Canadian 614 Journal of Fisheries and Aquatic Sciences 50, 1308-1317.

615 Ulanowicz, R.E., 1986. Growth and development: ecosystem phenomenology. Springer-

616 Verlag, New-York, USA. 203 pp.

617 Ulanowicz, R.E., Puccia, C.J., 1990. Mixed trophic impacts in ecosystems. Coenoses 5, 7-16. 618 619 


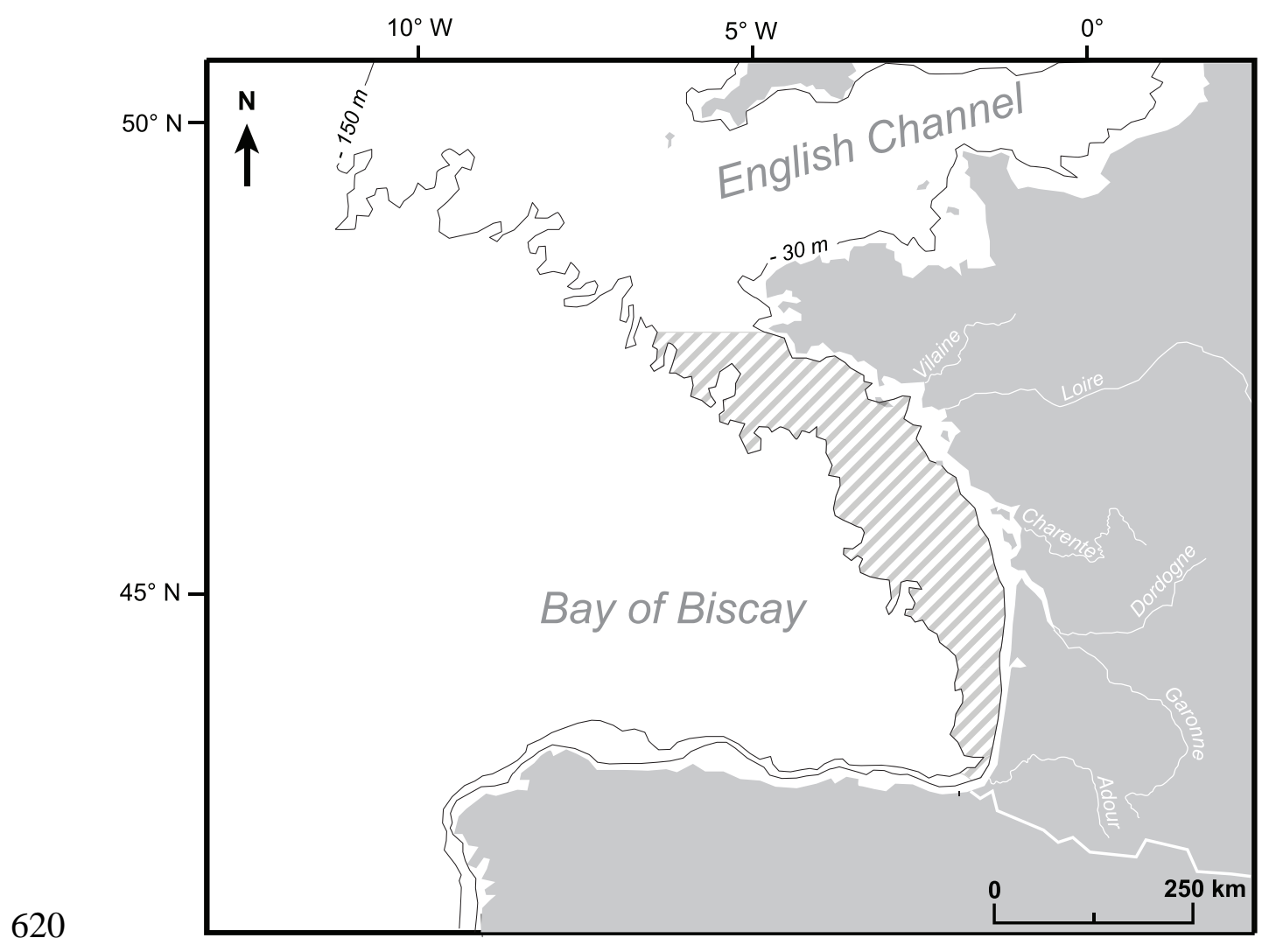




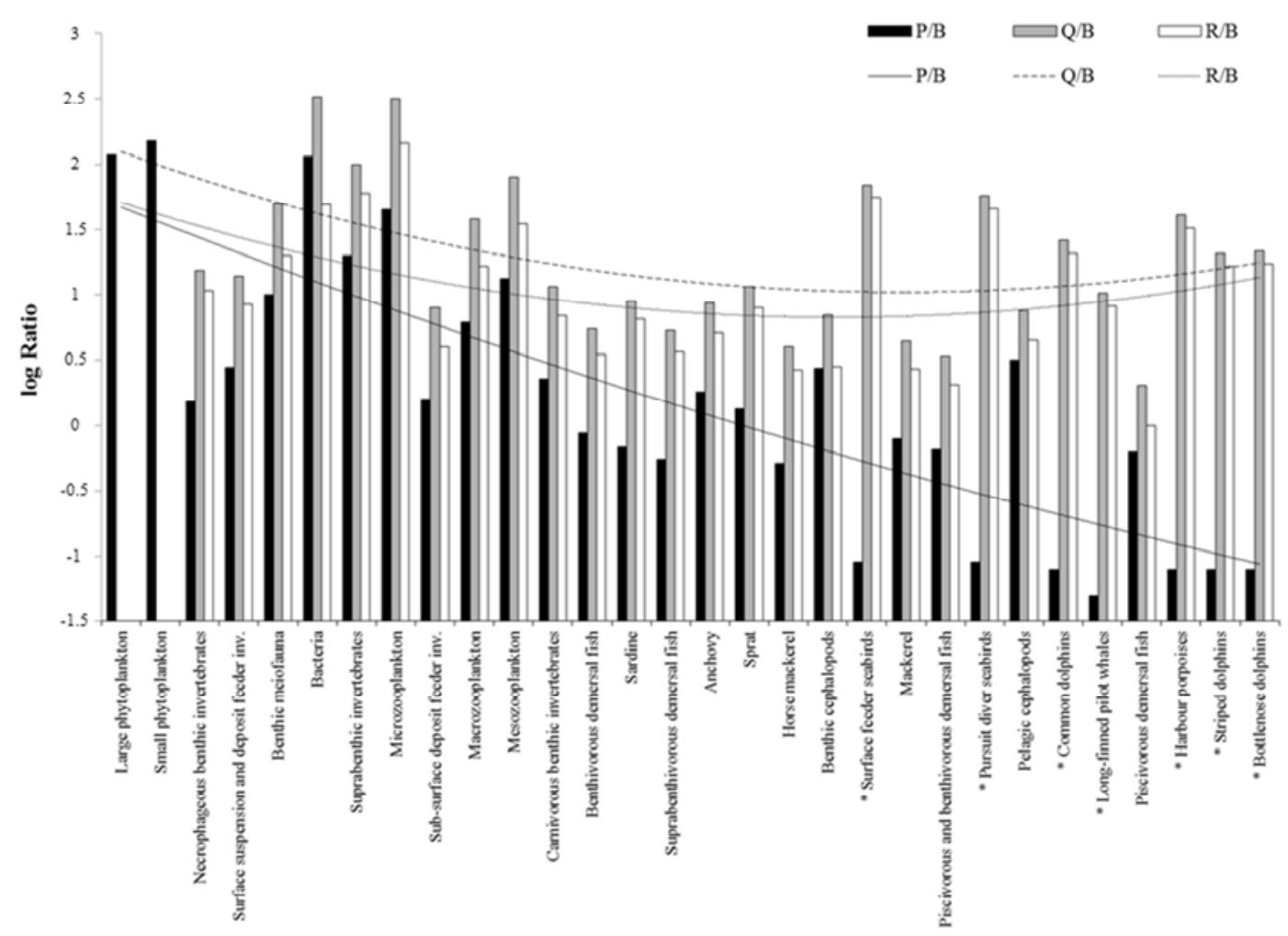




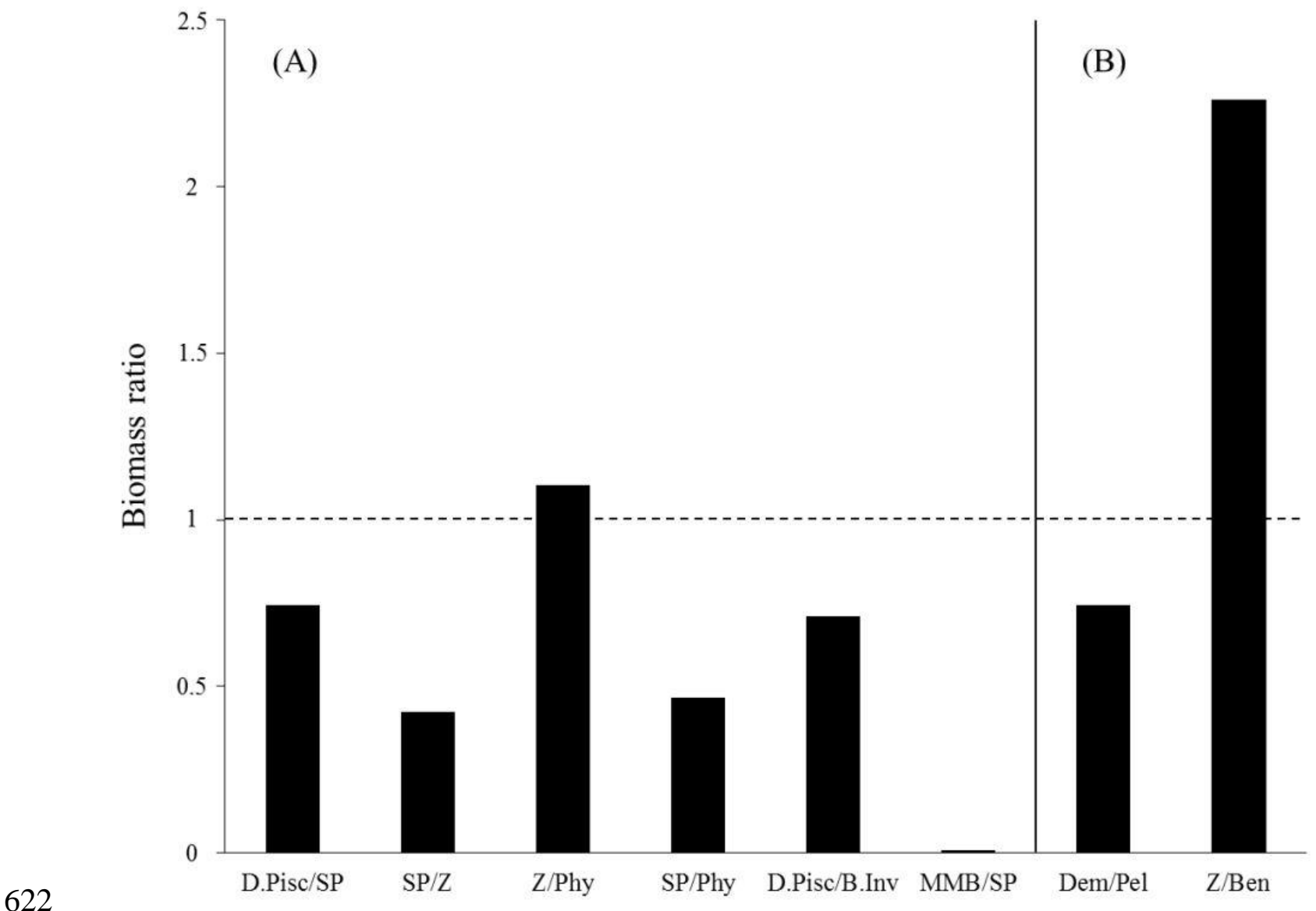




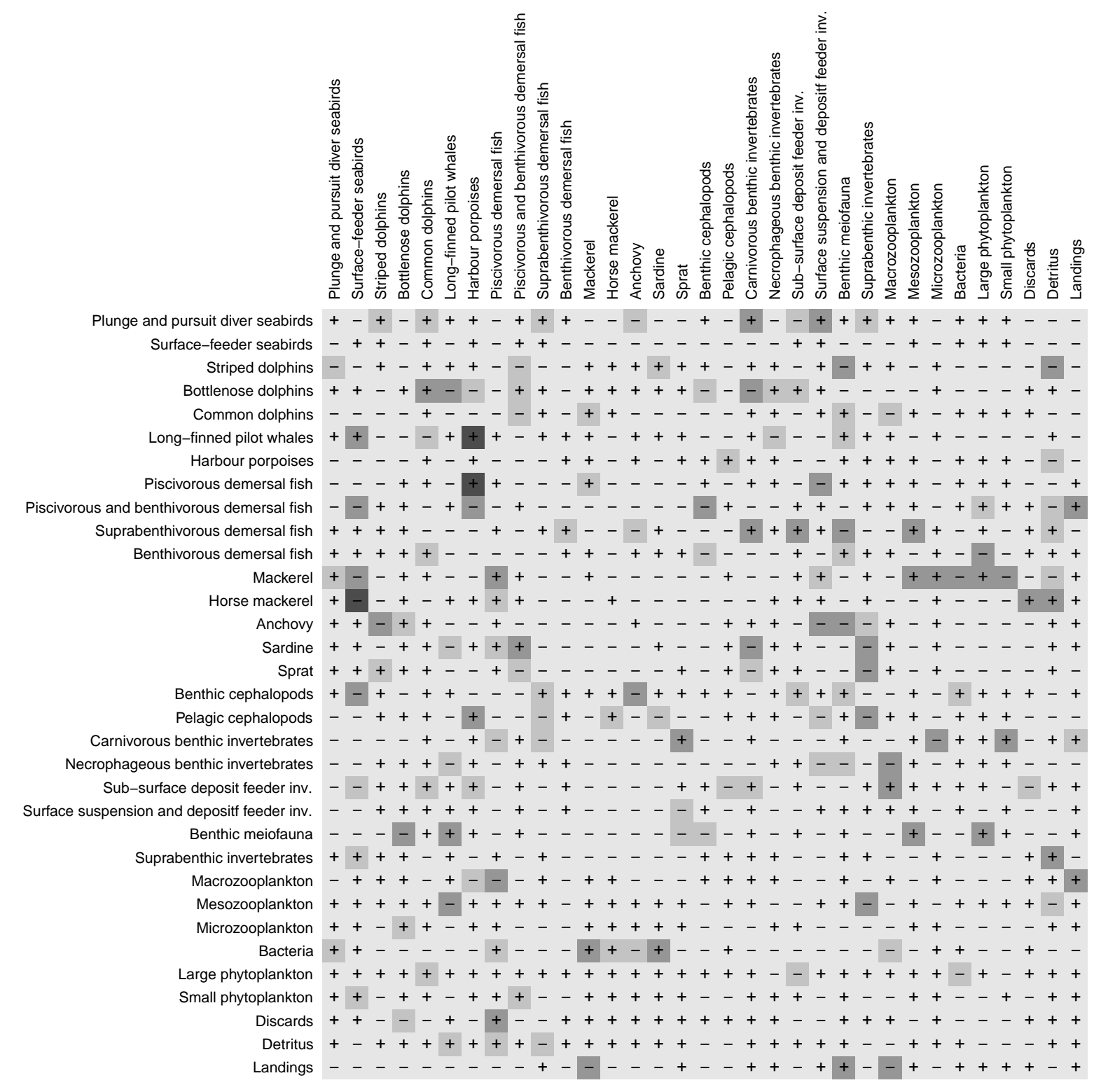


Appendix A. Input (regular) and output (bold) parameters for the ecosystem components used in the Bay of Biscay continental shelf model. $T L$ : trophic level, $B$ : biomass $\left(\mathrm{kg} \mathrm{C} \mathrm{km}^{-2}\right), P / B$ : production/biomass ratio (year ${ }^{-1}$ ), $Q / B$ : consumption/biomass ratio (year ${ }^{-1}$ ), $E E$ : ecotrophic efficiency, $P / Q$ : gross food conversion efficiency, $U / Q$ : unassimilated consumption, landings $(Y)$ and discards expressed in $\mathrm{kg} \mathrm{C} \cdot \mathrm{km}^{-2} \cdot \mathrm{year}^{-1}$.

\begin{tabular}{|c|c|c|c|c|c|c|c|c|c|}
\hline & $T L$ & $B$ & $P / B$ & $Q / B$ & $E E$ & $P / Q$ & $U / Q$ & $Y$ & Discards \\
\hline 1. Plunge and pursuit diver seabirds & 4.36 & 0.27 & 0.09 & 57.66 & $\mathbf{0}$ & 0.002 & 0.2 & & \\
\hline 2. Surface-feeder seabirds & 3.72 & 0.07 & 0.09 & 69.96 & $\mathbf{0}$ & 0.001 & 0.2 & & \\
\hline 3. Striped dolphins & 4.73 & 0.59 & 0.08 & 20.80 & $\mathbf{0}$ & 0.004 & 0.2 & & \\
\hline 4. Bottlenose dolphins & 5.18 & 2.18 & 0.08 & 21.67 & $\mathbf{0}$ & 0.004 & 0.2 & & \\
\hline 5. Common dolphins & 4.61 & 1.44 & 0.08 & 26.11 & 0.875 & 0.003 & 0.2 & & 0.101 \\
\hline 6. Long-finned pilot whales & 4.64 & 0.83 & 0.05 & 10.34 & $\mathbf{0}$ & 0.005 & 0.2 & & \\
\hline 7. Harbour porpoises & 4.69 & 0.12 & 0.08 & 40.69 & 0.833 & 0.002 & 0.2 & & 0.0078 \\
\hline 8. Piscivorous demersal fish & 4.66 & 48.45 & 0.63 & 2.03 & 0.991 & 0.311 & 0.2 & 10.42 & \\
\hline 9. Piscivorous and benthivorous demersal fish & 4.01 & 130 & 0.66 & 3.42 & 0.981 & 0.192 & 0.2 & 10.68 & 13.82 \\
\hline 10. Suprabenthivorous demersal fish & 3.49 & 311.20 & 0.55 & 5.30 & 0.765 & 0.104 & 0.2 & 0.64 & 26.79 \\
\hline 11. Benthivorous demersal fish & 3.41 & 28.97 & 0.88 & 5.51 & 0.949 & 0.159 & 0.2 & 5 & 0.20 \\
\hline 12. Mackerel & 3.73 & 145.93 & 0.79 & 4.40 & 0.978 & 0.181 & 0.2 & 6.24 & 0.49 \\
\hline 13. Horse mackerel & 3.69 & 262.21 & 0.51 & 4.00 & 0.987 & 0.128 & 0.2 & 16.81 & 1.01 \\
\hline 14. Anchovy & 3.67 & 55.75 & 1.82 & 8.68 & 0.825 & 0.210 & 0.2 & 16.80 & \\
\hline 15. Sardine & 3.44 & 184.23 & 0.68 & 8.97 & 0.787 & 0.076 & 0.2 & 10.82 & \\
\hline 16. Sprat & 3.67 & 49.78 & 1.34 & 11.59 & 0.679 & 0.116 & 0.2 & & \\
\hline 17. Benthic cephalopods & 3.70 & 10.40 & 2.75 & 7.00 & 0.950 & 0.393 & 0.2 & 3.53 & \\
\hline 18. Pelagic cephalopods & 4.44 & 14.11 & 3.20 & 7.50 & 0.950 & 0.427 & 0.2 & 1.99 & \\
\hline 19. Carnivorous benthic invertebrates & 3.23 & 116.75 & 2.30 & 11.50 & 0.999 & 0.200 & 0.2 & 2.91 & 1.09 \\
\hline 20. Necrophagous benthic invertebrates & 2 & 16.97 & 1.53 & 15.30 & 0.908 & 0.100 & 0.2 & & \\
\hline 21. Sub-surface deposit feeder inv. & 2.34 & 234.83 & 1.60 & 8 & 0.834 & 0.200 & 0.3 & & \\
\hline 22. Surface suspension and deposit feeder inv. & 2 & 223.93 & 2.80 & 14 & 0.891 & 0.200 & 0.2 & & \\
\hline 23. Benthic meiofauna & 2 & 100 & 10 & 50 & 0.921 & 0.200 & 0.4 & & \\
\hline 24. Suprabenthic invertebrates & 2.14 & 38 & 20 & 100 & 0.936 & 0.200 & 0.2 & & \\
\hline 25. Macrozooplankton ( $\geq 2 \mathrm{~mm})$ & 2.57 & 120 & 6.13 & 38 & 0.950 & 0.161 & 0.4 & & \\
\hline 26. Mesozooplankton (0.2-2 mm) & 2.67 & 638 & 13.27 & 80 & 0.950 & 0.166 & 0.4 & & \\
\hline 27. Microzooplankton $(\leq 0.2 \mathrm{~mm})$ & 2.18 & 894 & 44.91 & 316 & 0.950 & 0.142 & 0.4 & & \\
\hline 28. Bacteria & 2 & 394 & 115 & 328.57 & 0.811 & 0.350 & 0.5 & & \\
\hline 29. Large phytoplankton ( $\geq 3 \mu \mathrm{m})$ & 1 & 1046 & 119 & & 0.851 & & & & \\
\hline 30. Small phytoplankton $(<3 \mu \mathrm{m})$ & 1 & 448 & 151 & & 0.752 & & & & \\
\hline 31. Discards & 1 & 46.67 & & & 0.731 & & & & \\
\hline 32. Detritus & 1 & 2800 & & & 0.973 & & & & \\
\hline
\end{tabular}


Predator/prey matrix (column/raw). The fraction of one compartment consumed by another is expressed as the fraction of the total diet, the sum of each column being equal to one.

$\begin{array}{llllllllllllll}1 . & 2 & 3 & 4 & 5 & 6 & 7 & 8 & 9 & 10 & 11 & 12 & 13 & 14\end{array}$

1. Plunge and pursuit diver seabirds

2. Surface-feeder seabirds

3. Striped dolphins

4. Bottlenose dolphins

5. Common dolphins

6. Long-finned pilot whales

7. Harbour porpoises

8. Piscivorous demersal fish

9. Piscivorous and benthivorous demersal fish

10. Suprabenthivorous demersal fish

11. Benthivorous demersal fish

12. Mackerel

13. Horse mackerel

14. Anchovy

15. Sardine

16. Sprat

17. Benthic cephalopods

18. Pelagic cephalopods

$\begin{array}{lllll}0.014 & 0.403 & 0.015 & 0.002 & 0.011\end{array}$

$\begin{array}{llllllll}0.097 & 0.200 & 0.031 & 0.085 & 0.240 & 0.160 & 0.030 & 0.010\end{array}$

\begin{tabular}{|c|c|c|c|c|c|c|c|c|c|c|c|c|}
\hline \multirow{3}{*}{0.100} & & 0.097 & 0.200 & 0.031 & 0.085 & 0.240 & 0.160 & 0.030 & & 0.010 & \multirow{3}{*}{0.017} & \multirow{3}{*}{0.010} \\
\hline & & 0.345 & 0.007 & 0.004 & 0.006 & 0.216 & 0.190 & 0.065 & 0.005 & 0.030 & & \\
\hline & & 0.148 & 0.100 & 0.032 & & 0.012 & 0.050 & 0.010 & & 0.010 & & \\
\hline 0.090 & 0.070 & & 0.023 & 0.056 & 0.004 & 0.009 & 0.090 & 0.09 & 0.005 & & 0.030 & 0.005 \\
\hline 0.140 & 0.070 & & 0.132 & 0.050 & 0.039 & 0.276 & 0.200 & 0.100 & 0.005 & 0.020 & 0.020 & 0.005 \\
\hline 0.070 & 0.130 & 0.002 & 0.002 & 0.226 & & 0.003 & 0.135 & 0.032 & 0.005 & & 0.011 & 0.005 \\
\hline 0.380 & 0.210 & & 0.031 & 0.449 & 0.006 & 0.213 & 0.120 & 0.050 & 0.005 & & 0.009 & 0.007 \\
\hline 140 & 0.110 & & 0.009 & 0.080 & & & 0.055 & 0.018 & 0.005 & & 0.007 & 0.005 \\
\hline & & 0.006 & & 0.032 & 0.243 & 0.009 & & 0.010 & 0.002 & 0.003 & & \\
\hline & & 0.122 & 0.093 & 0.025 & 0.006 & 0.008 & & 0.005 & 0.003 & 0.007 & 0.005 & 0.010 \\
\hline & & & & & & & & 0.275 & & 0.200 & & 0.020 \\
\hline & & & & & & & & 0.020 & & 0.050 & & \\
\hline & & & & & & & & 0.030 & & 0.120 & & \\
\hline & & & & & & & & 0.235 & & 0.540 & & \\
\hline
\end{tabular}

invertebrates

20. Necrophagous benthic invertebrates

21. Sub-surface deposit feeders inv.

$0.235 \quad 0.540$

22. Surface suspension and deposit feeders inv.

23. Benthic meiofauna

24. Suprabenthic invertebrates

25. Macrozooplankton ( $\geq 2 \mathrm{~mm})$

26. Mesozooplankton $(0.2-2 \mathrm{~mm})$

0.120

0.050

$0.010 \quad 0.380$

0.010

27. Microzooplankton $(\leq 0.2 \mathrm{~mm})$

0.175

0.410

$0.213 \quad 0.150$

$\begin{array}{lll}0.655 & 0.723 & 1\end{array}$

0.0330 .050

28. Bacteria

29. Large phytoplankton $(\geq 3 \mu \mathrm{m})$

30. Small phytoplankton $(<3 \mu \mathrm{m})$

31. Discards

$0.080 \quad 0.290$

0.020

0.010

32. Pelagic detritus

Import 
2. Surface-feeder seabirds

3. Striped dolphins

4. Bottlenose dolphins

5. Common dolphins

6. Long-finned pilot whales

7. Harbour porpoises

8. Piscivorous demersal fish

9. Piscivorous and benthivorous demersal fish

10. Suprabenthivorous demersal fish

11. Benthivorous demersal fish

12. Mackerel

13. Horse mackerel

14. Anchovy

15. Sardine

16. Sprat

17. Benthic cephalopods

18. Pelagic cephalopods

19. Carnivorous benthic invertebrates

20. Necrophagous benthic invertebrates

21. Sub-surface deposit feeders inv.

22. Surface suspension and deposit feeders inv.

23. Benthic meiofauna

24. Suprabenthic invertebrates

25. Macrozooplankton $(\geq 2 \mathrm{~mm})$

26. Mesozooplankton $(0.2-2 \mathrm{~mm})$

27. Microzooplankton $(\leq 0.2 \mathrm{~mm})$

0.8001

0.090

$\begin{array}{lll}0.060 & 0.100 & \\ & 0.070 & 0.005 \\ 0.002 & & \\ & 0.190 & \\ & 0.085 & \\ & 0.080 & \\ & 0.057 & \\ & 0.073 & \\ 0.040 & 0.035 & 0.004 \\ & 0.050 & 0.005 \\ 0.210 & 0.050 & 0.051 \\ & & 0.005 \\ 0.079 & & 0.205 \\ 0.079 & & 0.270 \\ & & 0.210 \\ 0.180 & 0.090 & 0.035 \\ 0.350 & 0.090 & 0.060 \\ & 0.030 & 0.110\end{array}$

0.110

\section{$\begin{array}{lll}0.050 & 0.200 & 0.050\end{array}$ \\ $\begin{array}{llll}0.050 & 0.200 & 0.500 & 0.040\end{array}$ \\ 0.130}

$\begin{array}{llllll}0.600 & 0.100 & 0.900 & 0.600 & 0.300 & 0.290\end{array}$

0.180

$0.010 \quad 0.020$

$\begin{array}{lllll}0.030 & 0.980 & 0.660 & 0.400 & 0.900\end{array}$ 
Trophic model of the Bay of Biscay continental shelf. Boxes are arranged using trophic-level (TL) as y-axis and benthic/pelagic partitioning as xaxis. The size of each box is proportional to the biomass it represents. Numbers refer to a code for compartments provided in tables above. Benthic and pelagic food chains appeared to be linked mainly in their upper ranges by demersal fishes, particularly suprabenthivorous species. They optimize foraging benefits by feeding from both systems and they are, in turn, consumed by a large panel of pelagic top-predators.

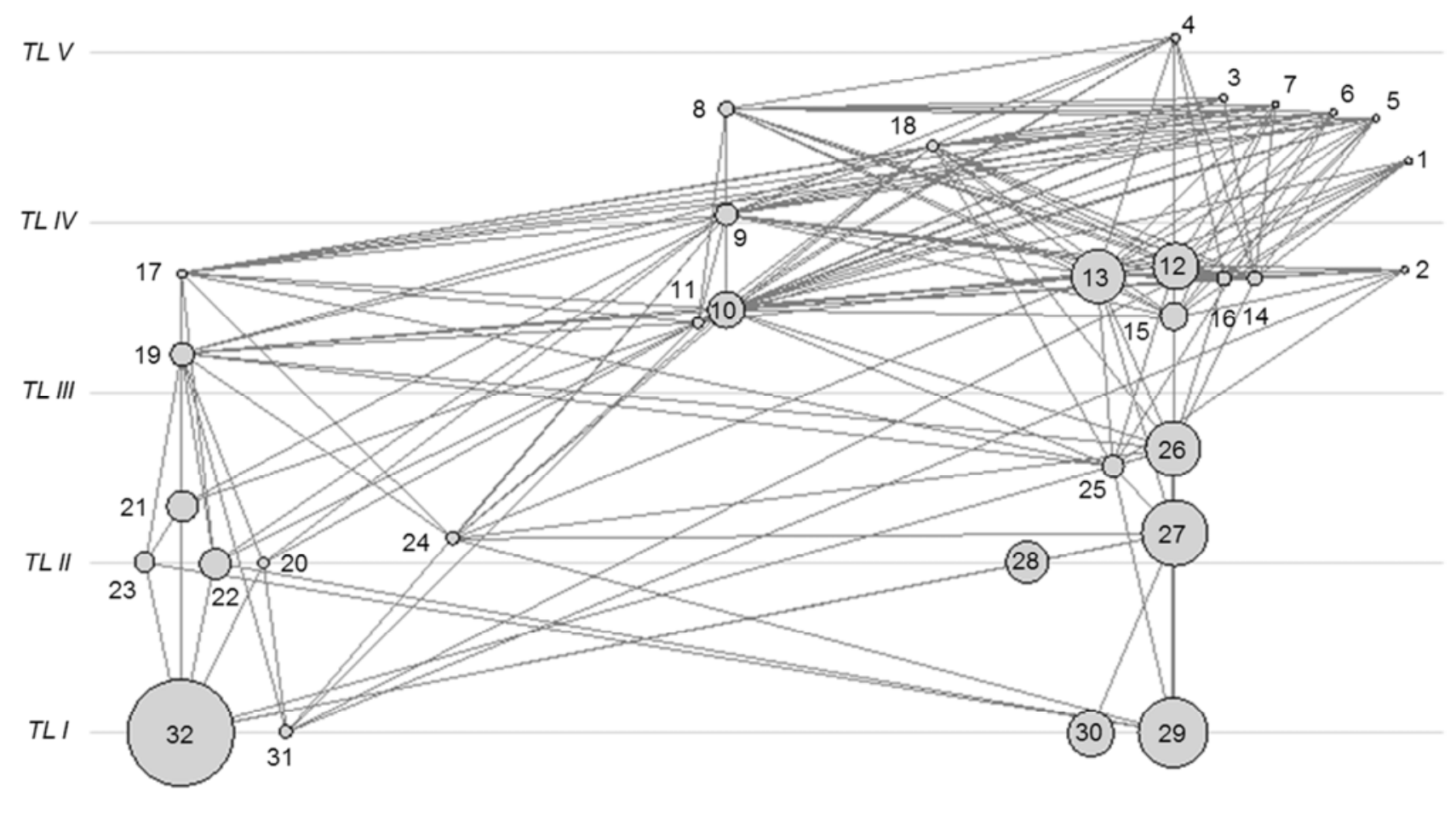

Benthic domain

Pelagic domain 
Appendix B. Pre-defined tables for each type of input parameters used in Pedigree analysis. A coded statement categorizes the origin a given input. Index refers to the values used to calculate the overall pedigree index of a given model. A confidence interval is suggested for each category.

\begin{tabular}{|c|c|c|c|c|}
\hline Parameter & Category & Description & Index & $\begin{array}{l}\text { Default confidence interval } \\
(+/-\%)\end{array}$ \\
\hline \multirow[t]{6}{*}{ Biomass $(B)$} & 1 & Missing parameter (estimated by Ecopath) & 0.0 & n.a. \\
\hline & 2 & From other model & 0.0 & 80 \\
\hline & 3 & Guesstimates & 0.0 & 80 \\
\hline & 4 & Approximate or indirect method & 0.4 & $50-80$ \\
\hline & 5 & Sampling based, low precision & 0.7 & 40 \\
\hline & 6 & Sampling based, high precision & 1.0 & 10 \\
\hline \multirow[t]{8}{*}{$P / B$ and $Q / B$} & 1 & Missing parameter (estimated by Ecopath) & 0.0 & n.a. \\
\hline & 2 & Guesstimates & 0.1 & 90 \\
\hline & 3 & From other model & 0.2 & 80 \\
\hline & 4 & Empirical relationships & 0.5 & 50 \\
\hline & 5 & Similar group/species, similar system & 0.6 & 40 \\
\hline & 6 & Similar group/species, same system & 0.7 & 30 \\
\hline & 7 & Same group/species, similar system & 0.8 & 20 \\
\hline & 8 & Same group/species, same system & 1.0 & 10 \\
\hline \multirow[t]{6}{*}{ Diets $(D C)$} & 1 & General knowledge of related group/species & 0.0 & 80 \\
\hline & 2 & From other model & 0.0 & 80 \\
\hline & 3 & General knowledge for same group/species & 0.2 & 80 \\
\hline & 4 & Qualitative diet composition study & 0.5 & 50 \\
\hline & 5 & Quantitative but limited diet composition study & 0.7 & 40 \\
\hline & 6 & Quantitative, detailed, diet composition study & 1.0 & 30 \\
\hline \multirow[t]{2}{*}{ Catches } & 1 & Guesstimates & 0.0 & $>80$ \\
\hline & 2 & From other model & 0.0 & $>80$ \\
\hline
\end{tabular}




\begin{tabular}{llll}
3 & FAO statistics & 0.2 & 80 \\
4 & National statistics & 0.5 & 50 \\
5 & Local study, low precision/incomplete & 0.7 & 30 \\
6 & Local study, high precision/complete & 1.0 & 10 \\
\hline
\end{tabular}


Appendix C. Construction of the Matrix Q using outputs from a given Ecopath models. The "Consumption" matrix represents the amount that a predator consumes of a given prey. Predators are represented by column and their prey by row. A zero indicates that a predator has no consumption of a given functional group. The "Flow to the detritus" column consists of what is egested (the non-assimilated food) and those elements of the group, which die of old age, diseases, etc. (the "other mortality" term in the first master equation). The "Fishery" column corresponds to landings. All three outputs for the present Ecopath model are expressed in $\mathrm{kg} \mathrm{C}$ $\mathrm{km}^{-2}$ year $^{-1}$. The Matrix $\mathrm{Q}$ is a square and non-symmetric matrix.

Four steps are required to obtain the original Q matrix:

(i) From Ecopath:

Consumption matrix
\begin{tabular}{|c|c|c|c|c|c|}
\hline $\begin{array}{c}\text { (parameterization - consumption) } \\
\text { Prey- } \\
\text { predator }\end{array}$ & 1 & 2 & 3 & $\ldots$. & Discards \\
\hline 1 & & & & & \\
\hline 2 & & & & & \\
\hline 3 & & & & & \\
\hline$\ldots$ & & & & & \\
\hline Discards & & & & & \\
\hline
\end{tabular}

Flow to detritus (parameterization - basic estimates)

\begin{tabular}{|c|c|}
\hline $\begin{array}{c}\text { Group } \\
\text { name }\end{array}$ & $\begin{array}{c}\text { Flow } \\
\text { to det. }\end{array}$ \\
\hline 1 & \\
\hline 2 & \\
\hline 3 & \\
\hline$\ldots$ & \\
\hline Discards & \\
\hline
\end{tabular}

Fishery

(parameterization - fishery - quantity)

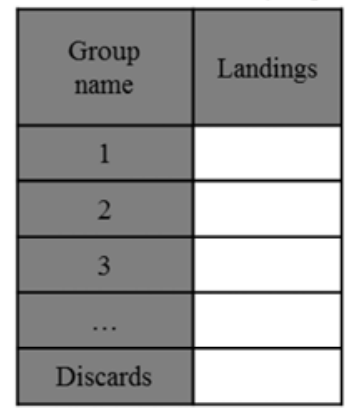

\begin{tabular}{|c|c|c|c|c|c|c|c|}
\hline Matrix A & 1 & 2 & 3 & 4 & Discards & Flow to det. & Landings \\
\hline \multicolumn{8}{|l|}{1} \\
\hline \multicolumn{8}{|l|}{2} \\
\hline \multicolumn{8}{|l|}{3} \\
\hline \multicolumn{8}{|l|}{4} \\
\hline$\ldots$ & & & & & & & \\
\hline Discards & & & & & & $\begin{array}{c}\text { Total } \\
\text { discards - } \\
\text { total discards } \\
\text { consumption }\end{array}$ & \\
\hline \multicolumn{8}{|l|}{ Detritus } \\
\hline \multicolumn{8}{|l|}{ Landings } \\
\hline $\begin{array}{l}\text { Sum by } \\
\text { column }\end{array}$ & & & & & & & \\
\hline
\end{tabular}

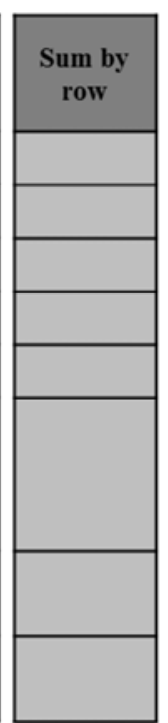


(ii) $\quad \mathrm{F}=\mathrm{A} /$ Sum by row

The "Flow to the detritus" column was not integrated in the calculation of the sums. In the end, $f_{d e t, i}$ values have to be set to zero.

(iii) $\quad \mathrm{D}=\mathrm{A} /$ Sum by column

The row corresponding to landings should be zeroes as no compartment "eat" the fishery.

(iv) $\quad \mathrm{Q}=\mathrm{D}-$ the transposed $\mathrm{F}$

Diagonal values have to be set to - 1 for matrix stability. Transposition means interchanging the rows and columns of a matrix. The matrix Q should be read as the net effect of a compartment in rows on a compartment in column.

(iv)' $\mathrm{Q}=$ the transposed $\mathrm{D}-\mathrm{F}$

The exact same matrix $Q$ is obtained except that it is the net effect of a compartment in column on the compartment in rows.

In the present study, the matrix Q was obtained with equation (iv). 
Appendix D. The R (www. r-project.org) code for the sensitivity analysis. The code is given for data stored in a three-sheet Excel file. The original matrix Q is stored in the "net_impacts" sheet and is obtained following steps (i) to (iv) described in Appendix C. The original matrix Q minus 20\% is in the "Com_Min" sheet and the original matrix Q plus 20\% in the "Com_Max" sheet. They all three give the net impact of a compartment in rows on the compartment in column.

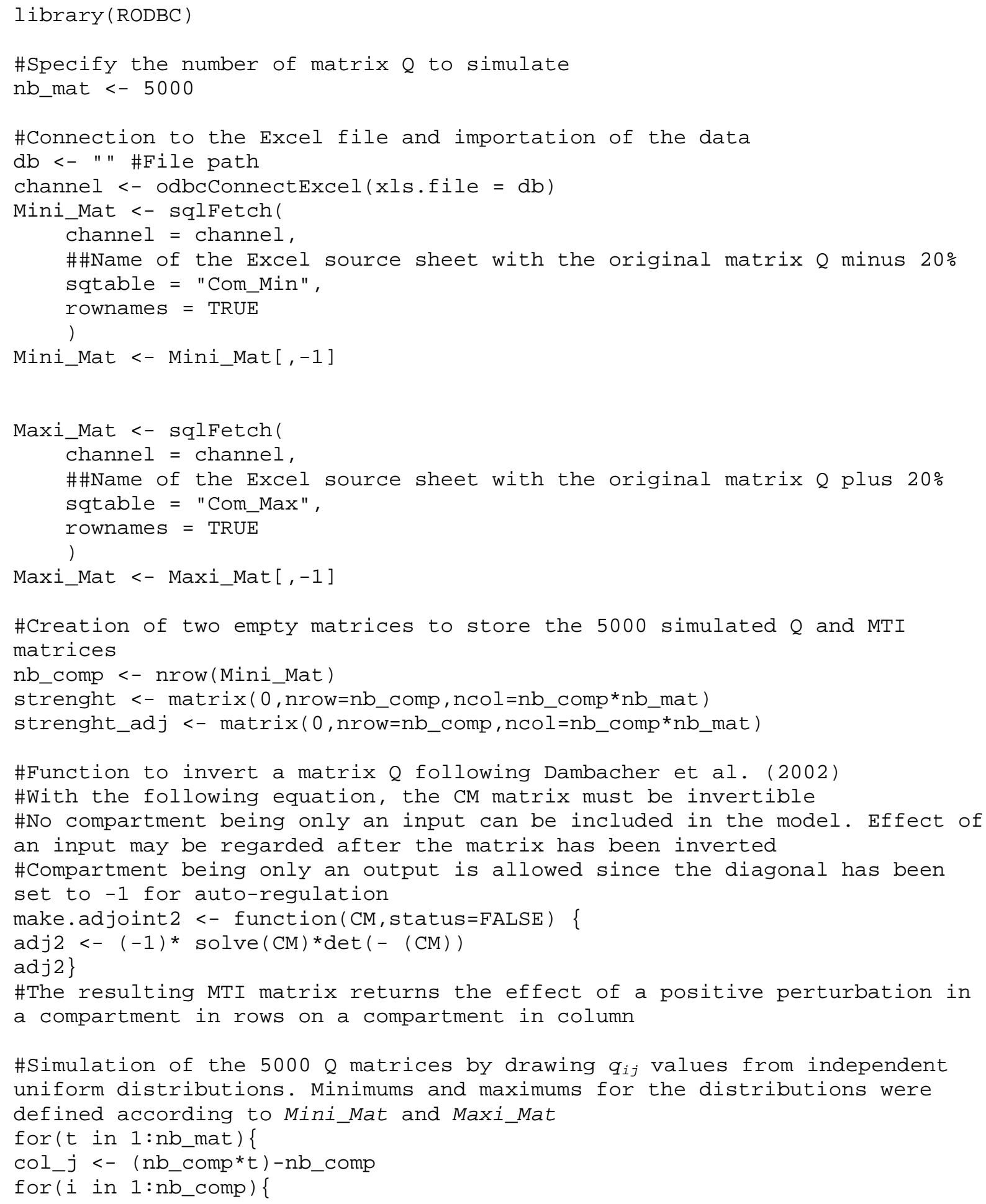




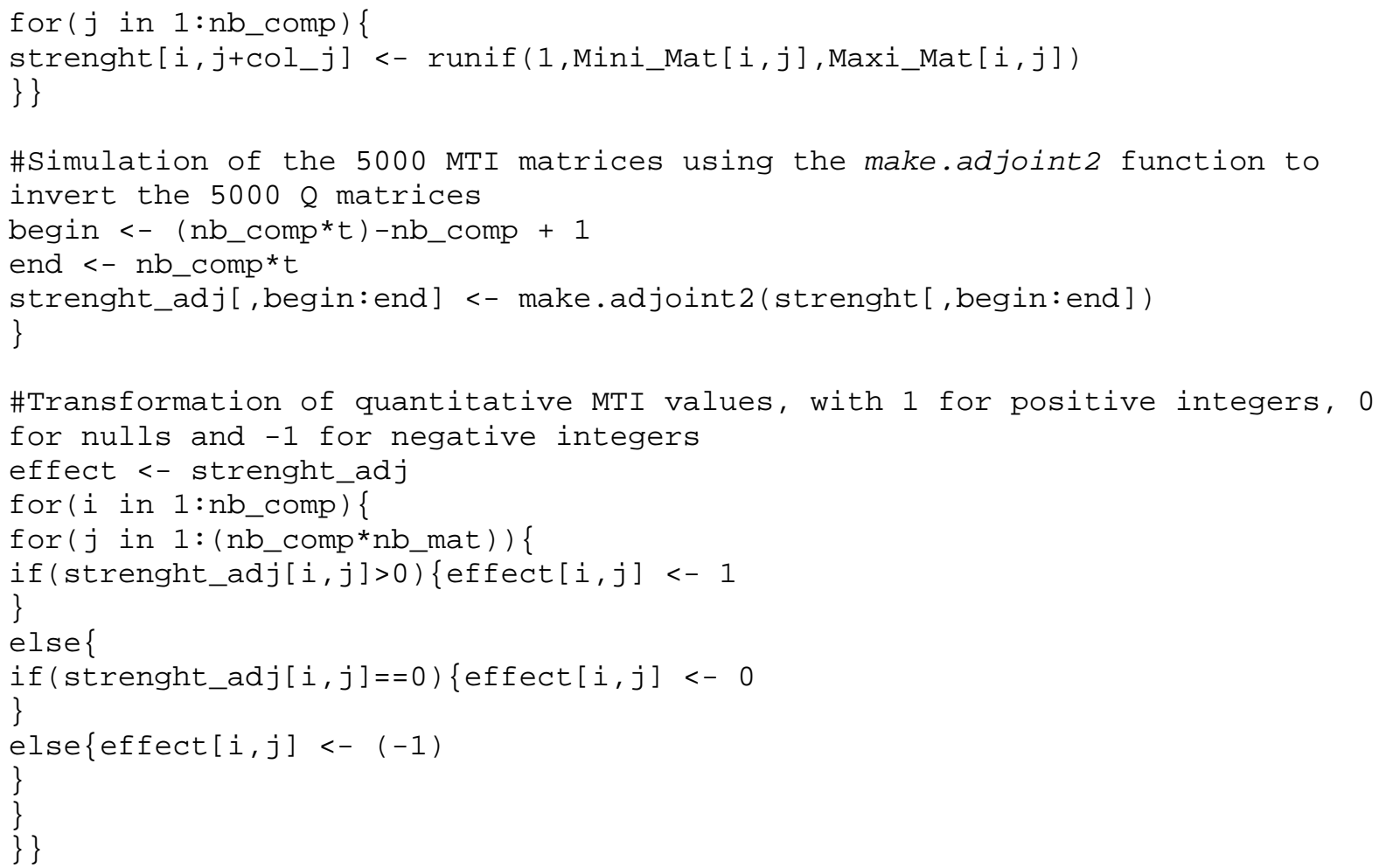

\#Inversion of the original $Q$ matrix resulting in the original MTI matrix Reference <- make.adjoint2 (Reference) 


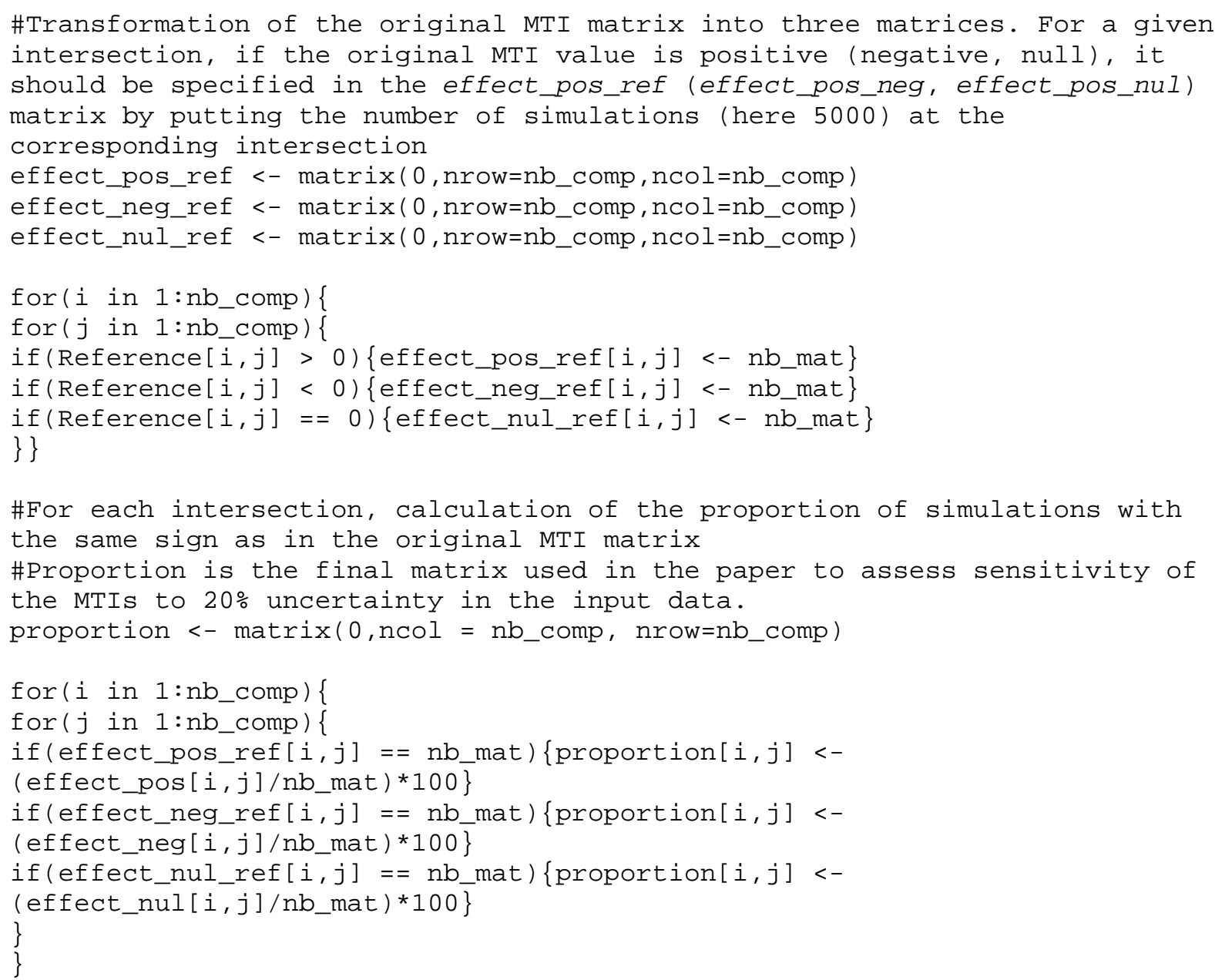

